\title{
Mapping elementary school students' creativity in science process skills of life aspects viewed from their divergent thinking patterns
}

\author{
*13ambang Subali; ${ }^{2}$ Paidi; ${ }^{3}$ Siti Mariyam \\ *Faculty of Mathematics and Natural Sciences, Universitas Negeri Yogyakarta \\ Jl. Colombo No. 1, Depok, Sleman 55281, Yogyakarta, Indonesia \\ *Email: b_subali@yahoo.co.id \\ Submitted: 10 March 2017 | Revised:11 July 2017 | Accepted: 11 July 2017
}

\begin{abstract}
The purpose of this study was to map elementary school students' creativity in science process skills (SPS) of life aspects in science subjects viewed from their divergent thinking patterns using written tests whose items were fitted with Partial Credit Model (PCM). The measurement used a test validated using the IRT approach published in JEE journal in 2015. The trials employed four sets of test, each comprising 20 items completed with anchor items which were fitted referring to PCM. The measurements were performed with larger scale on 14 regional technical implementation unit (RTIU) in Yogyakarta Special Province in five regencies/cities to students of grades IV, V, and VI. The findings show that the higher the grade level, the higher of the testees' scores would be. There were some testees who did not have divergent thinking ability and they obtained a score of 0 The divergent thinking ability of the students was not related to the regency/city where an RTIU was located.
\end{abstract}

Keywords: creativity, divergent thinking, science process skills, partial credit models

\section{How to cite item:}

Subali, B., Paidi, P., \& Mariyam, S. (2017). Mapping elementary school students' creativity in science process skills of life aspects viewed from their divergent thinking patterns. REiD (Research and Evaluation in Education), 3(1), 1-11. doi:http://dx.doi.org/10.21831/reid.v3i1.13294

\section{Introduction}

The core of teaching natural sciences is to teach the students to investigate natural phenomena to look for a scientific product by experiencing a scientific process with reference to scientific attitude (Carin \& Sund, 1989). A scientific process involves aspects of science process skills. A scientific process arranged in a particular order is called scientific method (Towle, 1989). The teaching that can enhance learners to master every aspect of the science process skills is badly needed in order that they can master the scientific process. The science process skills should be taught to students partially at the beginning. After mastering the aspects of science process skills, they are taught the science process skills as a unit of scientific method.

\section{Science Process Skills}

According to Rezba et al. (2007), science process skills can be divided into two aspects, namely basic skills and integrative skills. Basic skills include observing, communicating, classifying, measuring metrically, inferring, and predicting. Meanwhile, integrative skillls consist of identifying variables, constructing a table of data, constructing a graph, describing relationships between variables, acquiring and processing data, analyzing investigations, constructing hypotheses, defining variables operationally, designing experiments, and experimenting. 
Unlike Rezba et.al., Bryce, McCall, MacGregor, Robertson, and Weston (1990) divide science process skills into three aspects, namely basic skills, process skills, and investigative skills. Basic skills comprise of observational skills, recording skills, measurement skills, manipulative skills, procedural skills, and following instruction skills. While process skills are skills of inference and selection of procedures. Furthermore, investigative skills include skills to make plan and carry out a practical investigation.

In reference to The American Association for the Advancement of Science in 1965 (Chiappetta, 1997), science process skills are categorized into two, namely basic skills and integrated skills. Basic skills are skills of observing, classifying space time relations, using numbers, measuring, inferring, and predicting. Furthermore, integrated skills include such skills as defining, formulating models, controlling variables, interpreting data, hypothesizing, and experimenting.

Wenning (2005) says that science process skills can be classified into rudimentary skills, basic skills, intermediate skills, integrated skills, and advanced skills. Rudimentary skills comprise of observing, collecting and recording data; drawing conclusions; communicating and classifying results; measuring metrically; estimating; decision making 1; explaining; and predicting. Basic skills are skills of identifying variables, constructing a table of data, constructing a graph, describing relationships between variables, acquiring and processing data, analyzing investigations, defining variables operationally, designing investigations, experimenting, hypothesizing, decision making 2, developing models, and also controlling variables. Integrated skills include skills of identifying problems to investigate, designing and conducting scientific investigations, using technology and mathematics during investigations, generating principles through the process of induction, and communicating and defending a scientific argument. Advanced skills may consist of solving complex real world problems, synthesizing complex hypothetical explanations, establishing empirical laws on the basis of evidence and logic, analyzing and evaluating scientific arguments, constructing logical proofs, generating predictions through the process of deduction.

In 2010, Wenning (2010) revises the formulation of science process skills by adding one new skill namely culminating skills. Also, the revision includes the elaboration of each existing skill. The formulation of science process skills according to Wenning (2010) consists of rudimentary skills, basic skills, intermediate skills, integrated skills, culminating skills, and advanced skills. Rudimentary skills are skills of observing, formulating concepts, estimating, drawing conclusions, communicating results, and classifying results. Moreover, basic skills include predicting, explaining, estimating, acquiring and processing data, formulating and revising scientific explanations using logic and evidence, recognizing and analyzing alterative explanations and models. Meanwhile, intermediate skills comprise measuring, collecting and recording data, constructing a table of data, designing and conducting scientific investigations, using technology and math during investigations, and describing relationships.

The second aspect is integrated skills which include measuring metrically, establishing empirical laws on the basis of evidence and logic, designing and conducting scientific investigations, using technology and math during investigations. Furthermore, culminating skills comprise collecting, assessing, and interpreting data from a variety of sources, constructing logical arguments based on scientific evidence, making and defending evidencebased decisions and judgments, clarifying values in relation to natural and civil rights, and practicing interpersonal skills. Advanced skills are skills of synthesizing complex hypothetical explanations, analyzing and evaluating scientific arguments, generating predictions through the process of deduction, revising hypotheses and predictions in light of new evidence, and solving complex real-world problems.

\section{Creativity and Divergent Thinking}

Solving problems to find new products through scientific method is a process of inquiry. According to Mayer (1980), all science 
is inquiry. Biology is one kind of science. Biologists try to answer questions about living things.

Finding new products is a creative work. Creative thinking belongs to the high cognitive level in Bloom's taxonomy referring to Anderson, Krathwohl, and Bloom (2001) and Dettmer (2005). This tells that creativity can be taught to elementary school students. Meanwhile, Miller (2008) states that something that is not duplicated/imitated is categorized as creative.

In addition, Rule, Schneider, Tallakson, and Highnam (2012) who have quoted several sources state that elementary and middle school students who are high-achieving in science and who exhibit creativity are often not challenged or given the opportunity to fully utilize their abilities in regular classrooms. Many gifted students drop out because school is boring, repetitious, and lacks relevance to real life. They expect more exciting and challenging learning processes. Unfortunately, many classroom teachers lack sufficient background knowledge to design stimulating, advanced science projects for these students; some avoid science altogether.

In reference to Csikszentmihalyi's model of creativity (Peppler \& Solomou, 2011), individuals build on culturally valued practices and design to produce new variations of the domain, which, if deemed valuable by the community (i.e. the field), becomes part of what constitutes the evolving domain. Each component of the system continues to influence one another over time.

The rethinking of design for knowledge sharing is an important part of creating new work processes and has to evolve hand in hand with space planning (Mitchell, Inouye, \& Blumenthal, 2003). Hadzigeorgiou, Fokialis, and Kabouropoulou (2012) cited the opinion of Barrow (2010) that the inquiry in science will be able to develop students' creativity if there is an imaginative and divergent thinking process.

Measuring Creativity and Divergent Thinking Skills

Students' mastery of creativity should be measured. According to Kelly (2004), the existing research on creativity aims at measuring the divergent thinking as proposed by Torrance and creative personality developed by Gough. There is only little research which measures creativity as a multidimensional phenomena using self report scales which are valid and easy to administer.

The main problem in measuring creativity is ensuring what is measured is really creativity and is not affected by the measurement of intelligence (Cramond, 1994). Many studies regarding the strategies to measure creative thinking ability are compiled by Kind and Kind (2007). A detailed explanation about creativity tests which include a test to measure divergent thinking process is presented by Cropley (2000). Viewed from how to measure creativity, there are many ways and aspects that are measured. For instance, one of the strategies to measure the ability of divergent thinking can be classified based on the content and the products as reported by Meeker (1969).

Olivant (2009) says that according to Guilford (1950), creativity could and should be studied in non-eminent, 'everyday' people using psychometrics such as divergent thinking tasks (or paper and pencil tasks) to measure creative thinking. Torrance's Tests of Creative Thinking was created by Torrance (1979), and they are probably the best-known and most widely used creativity psychometric instruments. Sternberg and Lubart (1999) in Torrance (1979) state that many researchers viewed the tests as trivial and inadequate measures, while others charged that the tests, while possibly measuring aspects of creativity, failed to capture their essence.

The context dependency of creativity among students has been elaborated by Diakidoy \& Constantinou in 2000-2001 (Kind \& Kind, 2007) by getting as many responses as possible from three open ended assignment forms and scored based on divergent thinking skills of Guilford, namely: (a) fluency, i.e. the considerations in a given solution, (b) flexibility, i.e different types of solutions.

The science process skill measurement on different thinking aspects in siology subject of senior high school students in DIY and Central Java was performed by Subali 
(2009). In this case, the standardization of instrument utilized Item Response Theory or the IRT approach. This approach creates a calibration that puts learners' ability and item difficulty on the same scale. Therefore, they can be compared. The results show that the average score of creativity ability is much lower than the item difficulty index of the item to measure creativity.

Subali (2011) also measured high school students' creativity in the science process skills in biology subjects. The results are also relatively low. Subali and Mariyam (2013) have conducted a research concerning the development of science process skill creativity related to the aspects of life on science subjects that has been done by elementary school teachers. Most of the teachers stated that creativity had been taught to students in science subjects. However, the student's mastery on creativity has not been studied. Therefore, the creativity mastery of elementary school students on life aspects viewed from divergent thinking skills need to be investigated.

This research aimed at measuring the students' creativity in science process skills of life aspects viewed from divergent thinking patterns consisting of two aspects namely basic and process skills. The basic skill aspects have been published in the Journal of AsiaPacific Forum on Science Learning and Teaching, Volume 17, Issue 1, Article 2 (Jun., 2016) (Subali, Paidi, \& Mariyam, 2016).

The research aimed to map the creativity in science process skills (SPS) of life aspects of elementary school students in sciences subjects viewed from the divergent thinking pattern using written tests skills of which test items are fitted based on Partial Credit Model (PCM).

\section{Method}

The research was conducted for three years and consisted of three stages. The first stage is divided into two phases. In the first phase, the blue print of Science Process Skills (SPS) is developed. The blue print of SPS is formulated based on SPS blue prints produced by the research conducted by Subali (2009) used for measuring divergent thinking ability of SPS in biology subjects for senior high school students. In addition, the blue print is developed referring to several sources such as Rezba et al. (2007), Bryce et al. (1990), and Cox (1958). The SPS aspects include (a) basic skills and (b) process skills. This is considered as the difficulty to teach investigative skills to students of grades IV and V.

On the second phase, based on the blue print of SPS, creativity tests for SPS consisting of 63 items are developed. All items were judged by experts consisting of three lecturers --- all holding doctoral degrees --- of Biology Education Department. Using the divergent scoring model of Diakidoy and Constantinou (Kind \& Kind, 2007), the items were tested to 637 students of grades V and VI. The report of the instruments in this research were validated using the IRT approach in 2015 and was published in Journal of Elementary Education (JEE) Vol.25, No. 1 pp. 91-105 by Subali and Mariyam (2015). Based on the IRT approach, an item is declared to be able to measure the ability if it is fitted with the the model, in this case 1-PL (Rasch model). If all items are fitted with the model, the instruments can also be declared as valid (Wright \& Masters, 1982). The testing of fitted items on Rasch Model was carried out using the Quest program (Adams \& Khoo, 1993). On the third phase, the instrument was administered in large scale from elementary schools in Regional Technical Implementation Unit (RTIU) in DIY (Yogyakarta Special Province). The sample was established by using the purposive sampling technique by considering the characteristics of RTIU and school achievement through national examination. The sample testees were taken from 10 RTIUs in five regencies/cities in DIY. Two RTIUs from each regency/city were selected purposively. One of the RTIUs was located in the national capital and another was located far from the national capital, except for the RTIU in the city of Yogyakarta because both were in the city center. Moreover, two private elementary schools and four public elementary schools from each RTIU were selected. The test participants included students of grades IV, V, and VI. There were 2,563 testees of grade IV, 2,685 testees of grade $\mathrm{V}$, and 2,619 from grade VI. 


\section{Findings and Discussion}

Findings

After the instrument was administrated to elementary school students of grades IV, $\mathrm{V}$, and VI, the findings of the research are presented as follows. Table 1 shows that there is a reasonable increase of scores performed by elementary school students of grades IV to VI. This means that the higher the grade level, the greater the creativity score in Science Process Skill on life aspects mastered by the students will be. Compared to the fact that the total score which was achieved by grade 6 was 40 with the average score of 20 , it can be said that the achievement of the average score of 18.5 with the minimum score of 0 and maximum score of 38 is still relatively low, seen from the aspect of competence mastery.
Table 2 shows that the highest ranking of the creativity scores of divergent thinking model on Science Process Skills aspects of the fourth grade students in the five regencies/ cities is achieved by Sleman Regency. The score is higher than Yogyakarta City score as its capital. Meanwhile, the lowest score is achieved by Kulonprogo Regency. This indicates that the test results are not related to the characteristics of city or non-city regions.

Table 3 shows that the highest score of creativity in Science Process Skill on life aspects of the fifth grade elementary school students in five regencies/cities is achieved by the city of Yogyakarta, and the lowest score is Bantul Regency. This situation is different from that in the fourth grade.

Table 1. Creativity scores based on divergent thinking model of science process skill on life aspects in Natural Sciences subjects based on grades in DIY province.

\begin{tabular}{lcccccc}
\hline \multirow{2}{*}{ Grade } & \multirow{2}{*}{$\mathbf{N}$} & \multicolumn{5}{c}{ Score } \\
\cline { 3 - 7 } & & $\overline{\mathbf{y}}$ & $\mathbf{S}$ & Min & Max & Total \\
\hline Grade IV & 2563 & 12.8 & 6.7 & 0 & 37 & 40 \\
Grade V & 2685 & 15.3 & 6.5 & 0 & 36 & 40 \\
Grade VI & 2619 & 18.5 & 6.4 & 0 & 38 & 40 \\
\hline
\end{tabular}

Table 2. Creativity scores based on divergent thinking model of science process skill on life aspects in Natural Sciences subjects of the fourth grade students based on types of locations in DIY province

\begin{tabular}{|c|c|c|c|c|c|c|}
\hline \multirow{2}{*}{ Grade IV } & \multirow{2}{*}{$\mathbf{N}$} & \multicolumn{5}{|c|}{ Score } \\
\hline & & $\overline{\mathbf{y}}$ & $\mathrm{S}$ & Min & Max & Total \\
\hline Yogyakarta & 553 & 12.6 & 7.3 & 0 & 36 & 40 \\
\hline Bantul & 593 & 12.6 & 6.7 & 0 & 37 & 40 \\
\hline Sleman & 605 & 14.0 & 6.5 & 0 & 33 & 40 \\
\hline Kulonprogo & 380 & 11.4 & 6.0 & 0 & 29 & 40 \\
\hline Gunungkidul & 432 & 12.9 & 6.7 & 0 & 31 & 40 \\
\hline
\end{tabular}

Table 3. Creativity scores based on divergent thinking model of science process skill on life aspects in Natural Sciences subjects of the fifth grade students based on types of locations in

DIY province

\begin{tabular}{|c|c|c|c|c|c|c|}
\hline \multirow{2}{*}{ Grade $\mathrm{V}$} & \multirow{2}{*}{$\mathbf{N}$} & \multicolumn{5}{|c|}{ Score } \\
\hline & & $\overline{\mathbf{y}}$ & $\mathrm{S}$ & Min & $\operatorname{Max}$ & Total \\
\hline Yogyakarta & 534 & 16.9 & 6.6 & 0 & 36 & 40 \\
\hline Bantul & 632 & 13.5 & 6.3 & 0 & 34 & 40 \\
\hline Sleman & 688 & 16.4 & 6.3 & 1 & 35 & 40 \\
\hline Kulonprogo & 361 & 14.2 & 6.0 & 0 & 32 & 40 \\
\hline Gunungkidul & 470 & 15.2 & 6.5 & 0 & 36 & 40 \\
\hline
\end{tabular}


Table 4. Creativity scores based on divergent thinking model of science process skill on life aspects in Natural Sciences subjects of the sixth grade students based on types of locations in

DIY province

\begin{tabular}{|c|c|c|c|c|c|c|}
\hline \multirow{2}{*}{ Grade VI } & \multirow{2}{*}{$\mathbf{N}$} & \multicolumn{5}{|c|}{ Score } \\
\hline & & $\overline{\mathbf{y}}$ & $\mathbf{S}$ & Min & Max & Total \\
\hline Yogyakarta & 571 & 18.72 & 5.90 & 0 & 36 & 40 \\
\hline Bantul & 603 & 17.58 & 6.19 & 0 & 33 & 40 \\
\hline Sleman & 620 & 19.49 & 7.02 & 0 & 38 & 40 \\
\hline Kulonprogo & 335 & 18.15 & 6.04 & 2 & 34 & 40 \\
\hline Gunungkidul & 490 & 18.10 & 6.22 & 0 & 34 & 40 \\
\hline
\end{tabular}

Table 5. The mean scores and standard deviation of science process skills creativity on life aspects in Natural Sciences subject based on the types of RTIUs of the fourth grade students in DIY province

\begin{tabular}{|c|c|c|c|c|c|c|}
\hline \multirow{2}{*}{ Grade IV } & \multirow{2}{*}{$\mathbf{N}$} & \multicolumn{5}{|c|}{ Score } \\
\hline & & $\overline{\mathbf{y}}$ & $\mathbf{s}$ & Min & Max & Total \\
\hline \multicolumn{7}{|l|}{ Yogyakarta } \\
\hline East Yogyakarta & 134 & 23.2 & 17.5 & 0 & 88 & 120 \\
\hline West Yogyakarta & 419 & 34.5 & 18.8 & 0 & 88 & 120 \\
\hline \multicolumn{7}{|l|}{ Bantul } \\
\hline Bantul Selatan & 140 & 37.0 & 20.1 & 2 & 100 & 120 \\
\hline Banguntapan & 240 & 33.4 & 18.3 & 0 & 84 & 120 \\
\hline Piyungan & 213 & 25.6 & 14.9 & 0 & 65 & 120 \\
\hline \multicolumn{7}{|l|}{ Sleman } \\
\hline Sleman & 182 & 37.7 & 18.3 & 5 & 84 & 120 \\
\hline Kalasan & 256 & 34.8 & 16.7 & 0 & 86 & 120 \\
\hline Ngemplak & 167 & 32.7 & 16.7 & 2 & 88 & 120 \\
\hline \multicolumn{7}{|l|}{ Kulonprogo } \\
\hline Pengasih & 105 & 32.2 & 16.3 & 4 & 73 & 120 \\
\hline Kalibawang & 127 & 26.5 & 16.6 & 0 & 71 & 120 \\
\hline Sentolo & 148 & 27.0 & 14.1 & 0 & 70 & 120 \\
\hline \multicolumn{7}{|l|}{ Gunungkidul } \\
\hline Wonosari & 196 & 37.6 & 17.1 & 3 & 73 & 120 \\
\hline Panggang & 130 & 24.0 & 16.8 & 0 & 82 & 120 \\
\hline Purwosari & 106 & 32.9 & 15.5 & 0 & 71 & 120 \\
\hline
\end{tabular}

Table 4 shows that the highest score of Science Process Skills creativity of life aspects of the sixth grade students in five regencies/ cities is achieved by Sleman Regency, and the lowest is achieved by Kulon Progo Regency.

The followings are the results of the creativity measurement of Science Process Skill on life aspects in RTIUs of each regency/city ranging from grade IV to VI. Table 5 presents the results of measurements on the fourth grade.

Table 5 shows that the highest score of Science Process Skills creativity of life aspects of the fourth grade students in the five regencies/cities is achieved by the RTIU in Sleman
Regency. It is followed by Wonosari RTIU in Gunungkidul Regency, and South Bantul RTIU in Bantul Regency. While the low score that ranks XII is achieved by Piyungan RTIU in Bantul Regency, rank XIII is achieved by RTIU Panggang Gunungkidul and rank XIV is achieved by RTIU of East Yogyakarta. This may imply that the mastery of Science Process Skill creativity of life aspects on the fourth grade students is not dominated by students of the elementary school located in the capital of the province.

Table 6 presents the results of measurements of the grade V. It shows that the highest score of Science Process Skills creativity of 
life aspects of the fifth graders of elementary school in five regencies/cities in Yogyakarta RTIUs is achieved by the North Yogyakarta. Sleman Regency comes second and the third rank is achieved by RTIU of Ngemplak in Sleman Regency. While the low ranks, i.e rank
XII is achieved by Pengasih RTIU in Kulon Progo Regency, rank XIII is achieved by Banguntapan RTIU in Bantul Regency and rank XIV is achieved by Piyungan RTIU in Bantul Regency.

Table 6. The average scores and creativity standard deviation of science process skill of life aspects in Natural Sciences subject based on the types of RTIU of gade V students in DIY

\begin{tabular}{|c|c|c|c|c|c|c|}
\hline \multirow{2}{*}{ Grade V } & \multirow{2}{*}{$\mathbf{N}$} & \multicolumn{5}{|c|}{ Score } \\
\hline & & $\overline{\mathbf{y}}$ & $\mathbf{S}$ & Min & Max & Total \\
\hline \multicolumn{7}{|l|}{ Yogyakarta } \\
\hline East Yogyakarta & 122 & 35.8 & 18.4 & 0 & 88 & 120 \\
\hline West Yogyakarta & 412 & 45.5 & 17.4 & 0 & 98 & 120 \\
\hline \multicolumn{7}{|l|}{ Bantul } \\
\hline Bantul Selatan & 135 & 40.3 & 18.0 & 4 & 89 & 120 \\
\hline Banguntapan & 250 & 33.1 & 17.3 & 0 & 86 & 120 \\
\hline Piyungan & 247 & 31.3 & 15.4 & 1 & 72 & 120 \\
\hline \multicolumn{7}{|l|}{ Sleman } \\
\hline Sleman & 180 & 42.9 & 17.3 & 7 & 87 & 120 \\
\hline Kalasan & 297 & 40.4 & 18.0 & 3 & 93 & 120 \\
\hline Ngemplak & 211 & 41.6 & 17.0 & 6 & 94 & 120 \\
\hline \multicolumn{7}{|l|}{ Kulonprogo } \\
\hline Pengasih & 111 & 34.2 & 14.6 & 0 & 69 & 120 \\
\hline Kalibawang & 117 & 35.4 & 19.9 & 0 & 86 & 120 \\
\hline Sentolo & 133 & 36,0 & 12.9 & 10 & 81 & 120 \\
\hline \multicolumn{7}{|l|}{ Gunungkidul } \\
\hline Wonosari & 227 & 40.9 & 16.8 & 3 & 89 & 120 \\
\hline Panggang & 131 & 34.5 & 16.3 & 0 & 78 & 120 \\
\hline Purwosari & 112 & 37.3 & 20.3 & 0 & 99 & 120 \\
\hline
\end{tabular}

Table 7. The average scores and creativity standard deviation of science process skill of life aspects in Natural Sciences subject based on the types of RTIU of grade VI students in DIY

\begin{tabular}{lcccccc}
\hline \multicolumn{1}{c}{ Grade VI } & \multirow{2}{*}{$\mathbf{N}$} & \multicolumn{5}{c}{ Score } \\
\cline { 3 - 7 } & & $\overline{\mathbf{y}}$ & $\mathbf{S}$ & Min & Max & Total \\
\hline Yogyakarta & & & & & & \\
East Yogyakarta & 149 & 43.1 & 15.8 & 8 & 84 & 120 \\
West Yogyakarta & 422 & 48.7 & 16.2 & 0 & 98 & 120 \\
\hline Bantul & & & & & & \\
Bantul Selatan & 127 & 47.2 & 17.8 & 10 & 93 & 120 \\
Banguntapan & 256 & 43.6 & 18.7 & 0 & 86 & 120 \\
Piyungan & 220 & 43.7 & 14.4 & 9 & 78 & 120 \\
\hline Sleman & & & & & & \\
Sleman & 162 & 53.6 & 21.9 & 10 & 101 & 120 \\
Kalasan & 277 & 47.3 & 19.4 & 3 & 108 & 120 \\
Ngemplak & 181 & 49.4 & 18.2 & 0 & 103 & 120 \\
\hline Kulonprogo & & & & & & \\
Pengasih & 102 & 40.5 & 15.4 & 11 & 75 & 120 \\
Kalibawang & 102 & 52.5 & 17.1 & 16 & 92 & 120 \\
Sentolo & 131 & 44.2 & 15.4 & 4 & 84 & 120 \\
\hline Gunungkidul & & & & & & \\
Wonosari & 207 & 49.4 & 16.2 & 4 & 88 & 120 \\
Panggang & 138 & 43.6 & 18.2 & 0 & 90 & 120 \\
Purwosari & 145 & 41.9 & 15.9 & 3 & 85 & 120 \\
\hline
\end{tabular}


The results of the measurements on grade VI is presented in Table 7 which shows that the highest score of Science Process Skills creativity of life aspects of the sixth grade of elementary school students in five regencies/cities in Yogyakarta RTIUs is achieved by Sleman RTIU in Sleman Regency, rank II by Kalibawang RTIU in Kulon Progo Regency, and rank III by Wonosari RTIU in Gunung Kidul Regency. While the low ranks, i.e. rank XII is achieved by East Yogyakarta, rank XIII is achieved by Purwosari RTIU in Gunungkidul Regency and rank XIV is achieved by Pengasih RTIU of Kulon Progo Regency.

\section{Discussion}

The results of the research show that the average creativity ability of SPS on life aspects of the elementary school students of grades IV, V, dan VI in 14 RTIUs is low. On the contrary, based on the research conducted by Subali and Mariyam (2013), most teachers said that they had taught creativity to the students. This is probably because the teachers do not know well how to develop student's creativity. According to Dettmer (2005, pp. 70-78), creativity learning ideally must use an applied learning and an ideational learning model. In addition, teachers could encourage the students to be creative by giving examples on how to (a) substitute/replace, (b) combine, (c) adapt, (d) modify, add, (e) put something for another use, (f) eliminate or reduce and (g) reconstruct or reverse (Michalko, 2000).

Another reason is that the target of the teaching focuses on concept understanding. Therefore, creativity is not the main teaching target. Whereas, according to Burke-Adams (2007), it is very important to consider the learning needs of talented students in integrating creativity into a standard-based system.

Teachers are not aware that the goal of creativity development in natural sciences teaching is to direct the students to perform opened-discovery or inquiry or do the relevant tasks. Meanwhile, teachers are supposed to develop student's thinking in order that they can perform logical thinking creatively (Kind \& Kind, 2007, pp. 1-37). Teachers con- centrate more on developing students in order that they can understand the concept and automatically develop their convergent thinking skills. Teachers will rarely give questions with divergent answers (Croom \& Stair, 2005).

The teacher's worry regarding not to teach creativity to low academic potential students may not happen. The research findings of Ferrando, Prieto, Ferrandiz, and Sanchez (2005) tell that smart students are not always creative. Moreover, Cromie (2003) says that not all studies tell a correlation between students' IQ and creativity. In addition, Rawat, Qazi, and Hamid (2012) state that the development of creativity is closely linked to the development of skills to form a corresponding consideration in different situations. With regard to this, teachers should develop students' creativity as early as possible.

The findings indicate that there are two possibilities why elementary schools located in a big city are not always showing the highest scores. The first possibility is that the children are not potential. Thus, although the teachers develop creativity, the result may not be optimal. The second possibility is that children are assessed by their parents to be potentials so that they ask their children to go to elementary schools that are good based on the society assesment. For example, Ungaran, Serayu, and Muhammadiyah Sapen Elementary Schools. However, the score of RTIU in North Yogyakarta is not always the highest. Elementary schools in the area of RTIU Sleman are partially assessed by local people to be good schools and rank top. However, elementary schools in Kalibawang RTIU for grade VI rank second out of 14 RTIUs eventhough Kalibawang RTIU is located in the remote areas. Therefore, it seems that the teacher's role in developing the creativity of learners may not be optimal. Moreover, students in the sixth grade of elementary schools at cities probably more focus on the achievement of the high score national achievement in order to be received at junior high schools that are assessed good by the community based on the achievement on national examination. 


\section{Conclusion and Suggestions}

Based on the findings of the research, it can be concluded that a measuring instrument for Science Process Skills creativity of life aspects produced and tested in 2015 is relatively low. Recommendations are necessary to improve the ability of teachers in teaching Science Process Skill creativity of life aspects to students. The findings indicate that elementary schools located in remote areas RTIU may achieve high score probably because elementary school teachers in the city are more focusing on developing students to reach a high score of UN. It is worth exploring further using eksposfacto retrospective approach.

\section{Acknowledgement}

The deepest gratitude is addressed to the Directorate of Research and Community Service of the Ministry of Research, Technology, and Higher Education which has sponsored this research so that it can be carried out.

\section{References}

Adams, R. J., \& Khoo, S.-T. (1993). Acer Quest version 2.1. Camberwell, Victoria: Australian Council for Educational Research.

Anderson, L. W., Krathwohl, D. R., \& Bloom, B. S. (Eds.). (2001). A taxonomy for learning, teaching, and assessing: A revision of Bloom's taxonomy of educational objectives. New York, NY: Longman. https://doi.org/10.1207/s15430421 tip4 104_2

Bryce, T. G. K., McCall, J., MacGregor, J., Robertson, I. J., \& Weston, R. A. J. (1990). Techniques for assessing process skills in practical science: Teacher's guide. Oxford: Heinemann Educational Books.

Burke-Adams, A. (2007). The benefits of equalizing standards and creativity: Discovering a balance in instruction. Gifted Child Today, 30(1), 58-63.

Carin, A. A., \& Sund, R. B. (1989). Teaching science through discovery. Columbus, $\mathrm{OH}$ :
Merrill Publishing Company. Retrieved from https://books.google.co.id/books ?id=HopLAAAAYAAJ\&source=gbs_b ook_other_versions

Chiappetta, E. L. (1997). Inquiry-based science: Strategies and techniques for encouraging inquiry in the classroom. Science Teacher, 64(10), 22-26.

Cox, D. R. (1958). Planning of experiments. New York, NY: John Wiley \& Sons.

Cramond, B. (1994). We can trust creativity tests. Educational Leadership, 52(2), 70. Retrieved from http://ezproxy.lib. ucalgary.ca:2048/login?url=http:// searc h.ebscohost.com/login.aspx?direct $=$ tru $\mathrm{e} \& \mathrm{db}=\mathrm{ehh} \& \mathrm{AN}=9411032030 \&$ site $=\mathrm{eh}$ ost-live

Cromie, W. J. (2003). Creativity tied to mental illness: Irrelevance can make you mad. Harvard Gazette. Retrieved from https://news.harvard.edu/gazette/story /2003/10/creativity-tied-to-mentalillness/

Croom, B., \& Stair, K. (2005). Getting from $Q$ to A: Effective questioning for effective learning. The Agricultural Education Magazine, 78(1), 12-14. Retrieved from http://search.proquest. com $/$ docview $/ 224994858$ ? accountid $=8$ 579

Cropley, A. J. (2000). Defining and measuring creativity: Are creativity tests worth using? Roeper Review, 23(2), 72-79. https://doi.org/10.1080/02783190009 554069

Dettmer, P. (2005). New blooms in established fields: Four domains of learning and doing. Roeper Review, 28(2), 70-78. https://doi.org/10.1080/02783190609 554341

Ferrando, M., Prieto, M. D., Ferrandiz, C., \& Sanchez, C. (2005). Intelligence and creativity. Electronic Journal of Research in Educational Psychology, 3(3), 21-50. Retrieved from http:// www.investigacion-psicopedagogica.org /revista/new/english/ContadorArticul o.php?101 
Hadzigeorgiou, Y., Fokialis, P., \& Kabouropoulou, M. (2012). Thinking about creativity in science education. Creative Education, 3(5), 603-611. https://doi.org/10.4236/ce.2012.35089

Kelly, K. E. (2004). A brief measure of creativity among college students. College Student Journal, 38(4), 594-596.

Kind, P. M., \& Kind, V. (2007). Creativity in science education: Perspectives and challenges for developing school science. Studies in Science Education, 43(1), 1-37. http://dx.doi.org/10.1080/ 03057260708560225

Mayer, W. V (Ed.). (1980). Biological science: An inquiry into life (4th ed.). Denver, CO: Biological Sciences Curriculum Study.

Meeker, M. N. (1969). The structure of intellect: Its interpretation and uses. Columbus, $\mathrm{OH}$ : Merrill Publishing Company.

Michalko, M. (2000). Four steps toward creative thinking. The Futurist, 18-21. Retrieved from https:// www.questia.com/read/1G162026052/ four-steps-toward-creativethinking

Miller, P. W. (2008). Measurement and teaching. Munster, IN: Patrick W. Miller \& Associates.

Mitchell, W. J., Inouye, A. S., \& Blumenthal, M. S. (Eds.). (2003). Beyond productivity: Information, technology, innovation, and creativity (Committee). Washington, DC: The National Academies Press. Retrieved from https://www.nap.edu $/ \mathrm{read} / 10671 /$ chapter/1\#ii

Olivant, K. F. (2009). An interview study of teachers' perceptions of the role of creativity in a high-stakes testing environment. Fresno, CA: California State University.

Peppler, K. A., \& Solomou, M. (2011). Building creativity: Collaborative learning and creativity in social media environments. On the Horizon, 19(1), 1323. https://doi.org/10.1108/ 10748121111107672
Rawat, K. J., Qazi, W., \& Hamid, S. (2012). Creativity and education. Academic Research International, 2(2), 264-275.

Rezba, R. J., Sparague, C. S., Fiel, R. L., Funk, H. J., Okey, J. R., \& Jaus, H. H. (2007). Learning and assessing science process skills (3rd ed.). Dubuque, IA: Kendall/Hunt.

Rule, A. C., Schneider, J. S., Tallakson, D. A., \& Highnam, D. (2012). Creativity and thinking skills integrated into a science enrichment unit on flooding. Creative Education, 3(8), 1371-1379. https:// doi.org/10.4236/ce.2012.38200

Subali, B. (2009). Pengukuran keterampilan proses sains pola divergen dalam mata pelajaran biologi SMA di Provinsi DIY dan Jawa Tengah. Universitas Negeri Yogyakarta. Retrieved from http:/ eprints.uny.ac.id/4541/

Subali, B. (2011). Pengukuran kreativitas keterampilan proses sains dalam konteks assessment for learning. Cakrawala Pendidikan, 30(1), 130-144. https://doi.org/10.21831/cp.v1i1.4196

Subali, B., \& Mariyam, S. (2013). Pengembangan kreativitas keterampilan proses sains dalam aspek kehidupan organisme pada mata pelajaran IPA SD. Cakrawala Pendidikan, 32(3), 365-381. https://doi.org/10.21831/cp.v3i3.1625

Subali, B., \& Mariyam, S. (2015). Measuring the Indonesian elementary schools student's creativity in science processing skills of life aspects on natural sciences subject: In Yogyakarta Special Province (DIY). Journal of Elementary Education, 25(1), 91-105. Retrieved from https://www.google.co.id/url?sa=t\&rct $=\mathrm{j} \& \mathrm{q}=\&$ esrc $=\mathrm{s} \&$ source $=$ web\&cd $=1 \& \mathrm{c}$ $\mathrm{ad}=$ rja\&uact $=8 \&$ ved $=0 \mathrm{ahUKEwjK0tv}$ 7qNHWAhUJpo8KHbLECmsQFggn MAA\&url=http $\% 3 \mathrm{~A} \% 2 \mathrm{~F} \% 2 \mathrm{Fpu}$.edu.p $\mathrm{k} \% 2$ Fimages $\% 2 \mathrm{Fjournal} \% 2 \mathrm{FJEE} \% 2 \mathrm{FP}$ DF-Files\%2F6_v25_no1_15.pdf\&usg =AOvVaw0ZFHYs1ed_mQAOEFlsR pb9

Subali, B., Paidi, P., \& Mariyam, S. (2016). The divergent thinking of basic skills of 
sciences process skills of life aspects on natural sciences subject in Indonesian elementary school students. Asia-Pacific Forum on Science Learning and Teaching, 17(1). Retrieved from http:// proxy.library.vcu.edu/login?url=http:// search.proquest.com/docview/1871581 264 ? accountid $=14780 \% 5$ Cnhttp: $/ /$ vcualma-primo.hosted.exlibrisgroup.com/ openurl/VCU/vcu_services_page?url_v er=Z39.88-2004\&rft_val_fmt=info:ofi / fmt:kev:mtx:journal\&genre $=$ article

Torrance, E. P. (1979). A three-stage model for teaching for creative thinking. In A. E. Lawson (Ed.), The psychology of teaching for thinking and creativity (pp. 226-253). Columbus, $\mathrm{OH}$ : Association for Education of Teachers of Science, Ohio State University.

Towle, A. (1989). Modern biology. Austin, TX: Holt, Rinehart and Winston.
Wenning, C. J. (2005). Levels of inquiry: Hierarchies of pedagogical practices and inquiry processes. Journal of Physics Teacher Education Online, 2(3), 3-12. Retrieved from http:// scholar.google.com/scholar?hl=en\&btn $\mathrm{G}=$ Search\&q=intitle:Levels + of + inquir $\mathrm{y}:+$ Hierarchies + of + pedagogical + practi ces + and + inquiry + processes $\# 0$

Wenning, C. J. (2010). Level of inquiry: Using inquiry spectrum learning sequences to teach science. Journal of Physics Teacher Education Online, 5(3), 11-20. Retrieved from www2.phy.ilstu.edu/pte/ publications/learning_sequences.pdf

Wright, B. D., \& Masters, G. N. (1982). Rating scale analysis. Chicago, IL: Mesa Press. 